\title{
THERAPEUTIC EFFECTS OF GLUCOSAMINE SULFATE AND GINGER EXTRACT ON MONOSODIUM IODOACETATE INDUGED OSTEOARTHRITIS IN RATS.
}

\author{
By \\ Abd El-Ghany,M.A \\ Department of Home Economics, \\ Faculty of Specific Education, \\ Mansoura University, Egypt. \\ Sultan, Y.M. \\ Ghozy, S.F. \\ Department of Home Economics, \\ Faculty of Specific Education, \\ Mansoura University, Egypt. \\ Department of Home Economics, \\ Faculty of Specific Education, \\ Mansoura University, Egypt.
}

Research Gournal Specific Fducation

Faculty of Specific Education

Mansoura University

ISSUE NO. 50, APRIL. 2018

مجلة بحوث التربية النوعية - جامعة المنصورة

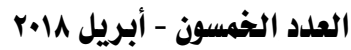




\title{
THERAPEUTIC EFFECTS OF GLUCOSAMINE SULFATE AND GINGER EXTRACT ON MONOSODIUM IODOACETATE INDUGED OSTEOARTHRITIS IN RATS.
}

\author{
Abd El-Ghany,M.A; Ghozy, S.F. and Sultan, Y.M.*
}

\section{Abstract}

Osteoarthritis is characterized by the progressive degradation of joint cartilage and secondary inflammation of synovial membranes. The present study was designed to investigate the effects of glucosamine sulfate (GLAS) and ginger (GR) water extract on the nutritional status and some biochemical changes of blood and Knee tissue in osteoarthritis rats. Thirty six healthy Sprague-Dawley adult albino rats were classified into six groups. The first and second groups were normal control and GLAS groups while the other four groups injected Knee intra-articular with monosodium iodoacetate to induce osteoarthritis. The osteoarthritis rats were classified into positive group and three treated groups with GLAS, ginger (GR) and GLAS+GR. Rats were sacrificed after 77 days. The obtained results indicated that, the osteoarthritis positive control group showed a significant decrease nutritional values and non significant difference of FER and showed a significant increase in serum levels of C- reactive protein (CRP), Erythrocyte sedimentation rate (ESR1 \& ESR2) and albumin / globulin ratio but showed a significant decrease in total protein, albumin, globulin and antioxidant enzymes in knee joint tissue compared with normal and GLAS groups. The osteoarthritis rat groups treated with glucosamine sulfate (T.GLAS) and ginger water extract (T.GR) showed significant increase of nutritional values total protein and albumin, and significant decrease in CRP, ESR1 and ESR2 and compared to positive control group. The osteoarthritis rat group which treated with both glucosamine and ginger (T.GLAS+ T. GR) showed a significant improvement of nutritional values and appear within normal, significant decrease in CRP, ESR1 and ESR2 compared with positive control group. All treated groups had a significant

* Department of Home Economics, Faculty of Specific Education, Mansoura University, Egypt. 
higher values of the tested antioxidants enzymes and lower value of MDA compared to positive group without reach the levels of normal control group.

The biochemical changes were confirmed with histopathological examination of knee joint, revealed that osteoarthritis rat treated with dose of glucosamine sulfate, water extract of ginger and both ginger with glucosamine were shown a very small recovery of knee joint, with small necrosis in cartilage surface. It can be concluded that the administration of glucosamine sulfate and water extract of ginger could ameliorate most the biochemical parameters. Dietary supplements of ginger with glucosamine are recommended to improve the antioxidant status of knee joint health.

Keywords: Osteoarthritis, Monosodium iodoacetate, Glucosamine sulfate, Ginger. Extract, rats

\section{INTRODUCTION}

Osteoarthritis (OA) is the most widespread degenerative joint disease and increases with age. OA can affects any joints in the body especially joints in knees, hands, spine, neck, lower back and small joints of the finger. Osteoarthritis can occur in any synovial joint in the body, results tissues of the joint erosion, impaired physical function and cartilage stiffness. Pain is the most widespread symptom of leads to walking difficulty, lack of movement, reduced activities, restlessness, and disturbances in life overall quality (Murray and Lopez, 2013)Wood et al., 2013; Choi et al., 2016). Dieppe and Lohmander, 2005; Lane et al., 2011; Litwic et al., 2013; Shimura et al., 2013). Glucosamine (GLAS) is an amino monosaccharide, available in connective tissue and cartilage, produced in the body from glucose (Jerosch, 2011). Glucosamine is a dietary supplement and may be good for treatment of osteoarthritis that can relieve the pain and slow the decomposition and collapse of cartilage in knee joint (Simanek et al., 2005).

Herbs and other plant materials are consumed as food or remedy for disease because of polyphenolics have antioxidant activity (Velioglu et al., 1998). Ginger (Zingiber officinale) is flowering plant used fresh or dried as 
a herbal medicine or a cooking condiment and flavoring especialy in Asia (Tepe et al., 2006). Ginger has been used for the treatment of indigestion, nausea, vomiting, diarrhea, hypertension, arthritis, rheumatism, muscular aches, asthma, and sore throats due to the bioactive ingredient which possesses pharmacological effects, antimicrobial and antioxidation (Ali et al., 2008 and Ghasemzadeh et al., 2010).Ginger root extract has an important role as an anti-arthritic agent, due to its inhibitory effects on nitric oxide and prostaglandin E2 and high significant effect on reducing symptoms and the pain of knee osteoarthritis. Ginger also reduces inflammatory reactions in synovial cells as effectively as steroids of osteoarthritis and rheumatoid arthritis models (Shen et al., 2005 and Madsen et al., 2012). The study aimed to investigate the comparative and therapeutic effects of glucosamine sulfate drug and aqua ginger extract against monosodium iodoacetate induced osteoarthritic in rats.

\section{MATERIALS AND METHODS}

\section{Materials:}

Thirty-six adult male of white albino rats (Sprague Dawley Strain) weighing $177 \pm 4 \mathrm{~g}$, were obtained from Agricultural Research Center, Giza, Egypt. Monosodium iodoacetate (MIA) powder was purchased commercially from Sigma-Aldrich Corporation American Chemicals Company. Glucosamine sulfate capsules ${ }^{\mathrm{TM}}$ drug was purchased from pharmacy of Mansoura city. Each capsule contains $500 \mathrm{mg}$ of glucosamine sulfate; the human therapeutic dosage of the drug was $1500 \mathrm{mg}$ daily. Ginger roots (zingiber officinale) were obtained from local market at Mansoura city, Dakahlia Governorate, Egypt.

\section{Methods}

The fresh Ginger root were thoroughly washed in distilled water, chopped into small pieces and sun dried, then grinded to powder. The aqueous extracts of the roots were subsequently prepared by soaking 300 grams of the powder in 3 liter of cold water for about 24 hour at room temperature. This homogenized mixture was then filtered and stored in the refrigerator till be used (Ahui et al., 2008). The basal diet was prepared 
according to NRC (1995). All the biological experimental procedures were applied in accordance with internationally guidelines for the care and use of laboratory animals. Ethical guidelines were maintained during animal handling and permission was obtained from the concerned Department.

Osteoarthritis induced in rats by a single dose of monosodium iodoacetate at dose $50 \mu \mathrm{g} / 1 \mathrm{~mL}$ saline of body weight injection intraarticular of the right Knee joint. The time required for the emergence of symptoms of OA After two weeks of MIA injection according to Guzman et al., (2003).

After adaptation period (eight days), Rats were randomly classified into six groups (six rats in each) as following:

1- Normal control group that did not received any treatment

2- GLAS group that received glucosamine sulfate in dose $20 \mathrm{mg} / \mathrm{kg} /$ bw/d

3- Positive control group that was osteoarthritic rats and did not receive any medication.

4- T.GLAS group that was osteoarthritic rats and treated with GLAS (20 mg/kg/ bw/d) according to Noushi and Al-Shawi (2013) by oral stomach tube.

5- T. GR group that was osteoarthritic rats and treated with ginger $(1 \mathrm{ml}$ $/ 100 \mathrm{~g} / \mathrm{b} . \mathrm{w} / \mathrm{d})$ by oral stomach tube.

6- T.GLAS+ T. GR group that was osteoarthritic rats and treated with GLAS( $20 \mathrm{mg} / \mathrm{kg} / \mathrm{bw} / \mathrm{d})$ and ginger (GR) $(1 \mathrm{ml} / 100 \mathrm{~g} / \mathrm{b} . \mathrm{w} / \mathrm{d})$ by oral stomach tube

Daily food intake and weekly body weight gain were recorded. After 77 days, the rats were anesthetized, blood sample were collected in clean centrifuge tubes to obtain serum. Erythrocyte sedimentation rate (ESR1\& ESR2) was analyzed by Westergen method according to Bull et al., (1993), While Sera were testing for determination of C- reactive protein levels (CRP) was measured depending on the method of (Chetana 1993). Total protein levels and albumin was estimated calorimetrically according to the method of Cannon et al., (1974) and Eastham (1976), respectively. Feed 
efficiency ratio (FER), Globulin levels and albumin/globulin ratio were calculated according to Chapman et al., (1959), Coles (1974) and Friedewald et al., (1972).

The articular capsule of the right knee joints were anatomized, frozen by liquid nitrogen and pulverize in a mortar pestle, then solubilized in $4 \mathrm{ml}$ of PBS (phosphate buffer saline, $\mathrm{pH}=7$ ) in order to obtain homogeneous tissue that centrifuged at $10000 \mathrm{rpm}$ for 10 minutes and the supernatants were collected. Malondialdehyde (MDA), superoxide dismutase (SOD), catalase, reduced glutathione (GSH) and glutathione peroxidase (GPx) using the procedure described by Mistura and Midora (1987), Nandi and Chatterjee 1988), Claiborne (1985), Ellman, (1959) and Necheles et al., (1968), respectively.

\section{Histopathological examination of knee joint specimens:}

The fixed samples of knee joint was achieved by using the chelating agent EDTA disodium salt (10\%) solution (5.5g EDTA in $90 \mathrm{ml}$ distilled water and 10ml formaldehyde, 37:40\%). The knee joint tissue was submerged in EDTA solution, and solution was changed daily for about four weeks until softening of specimens and embeded in paraffin 4-5 $\mu \mathrm{m}$ thick section and stained with Hematoxylin and Eosin (H\&E) for subsequent histopathological examination (Banchroft et al., 1996).

\section{Statistical data analysis:}

All tests were accomplish using computer package of the statistical analysis program (SPSS, version 24, 2016), the collected data were presented as means \pm standard deviations (means \pm S.D), statistically analyzed using one way analysis of Variance (ANOVA) according to Artimage and Berry (1987) 
- Therapeutic effects of glucosamine sulfate and ginger extract on monosodium iodoacetate

\section{RESULTS AND DISCUSSION}

\section{Nutritional evaluation:}

Table (1): Nutritional effects on normal and Osteoarthritic rat groups

\begin{tabular}{|c||c|c|c|c|c||}
\hline & $\begin{array}{c}\text { Final Weight } \\
(\mathrm{g})\end{array}$ & $\begin{array}{c}\text { Weight Gain } \\
(\mathrm{g})\end{array}$ & $\begin{array}{c}\text { Weight } \\
\text { Gain\% }\end{array}$ & $\begin{array}{c}\text { Food Intake } \\
(\mathrm{g})\end{array}$ & FER \\
\hline \hline Normal control & $228.00 \pm 6.75 \mathrm{a}$ & $50.17 \pm 3.19 \mathrm{a}$ & $28.12 \pm 1.38 \mathrm{a}$ & $16.87 \pm 0.23 \mathrm{a}$ & $0.04 \pm 0.003 \mathrm{a}$ \\
\hline GLAS & $228.17 \pm 7.91 \mathrm{a}$ & $50.67 \pm 2.50 \mathrm{a}$ & $28.57 \pm 1.56 \mathrm{a}$ & $17.31 \pm 0.21 \mathrm{a}$ & $0.04 \pm 0.002 \mathrm{a}$ \\
\hline Positive control & $205.00 \pm 6.42 \mathrm{c}$ & $28.83 \pm 3.25 \mathrm{c}$ & $16.35 \pm 1.56 \mathrm{c}$ & $12.50 \pm 0.81 \mathrm{bc}$ & $0.03 \pm 0.004 \mathrm{ab}$ \\
\hline T.GLAS & $214.50 \pm 8.29 \mathrm{~b}$ & $38.33 \pm 3.67 \mathrm{~b}$ & $21.74 \pm 1.79 \mathrm{~b}$ & $13.83 \pm 0.17 \mathrm{~b}$ & $0.04 \pm 0.004 \mathrm{a}$ \\
\hline T. GR & $213.00 \pm 10.43 \mathrm{~b}$ & $35.67 \pm 4.13 \mathrm{~b}$ & $20.07 \pm 1.76 \mathrm{~b}$ & $13.47 \pm 0.16 \mathrm{~b}$ & $0.03 \pm 0.004 \mathrm{ab}$ \\
\hline T.GLAS+ T GR & $221.00 \pm 9.01 \mathrm{a}$ & $44.83 \pm 7.06 \mathrm{a}$ & $25.44 \pm 3.92 \mathrm{a}$ & $15.90 \pm 0.07 \mathrm{a}$ & $0.04 \pm 0.006 \mathrm{a}$ \\
\hline
\end{tabular}

Mean \pm SD values in each column having different combinations of superscript letters $(\mathrm{a}, \mathrm{b}, \mathrm{c}, \mathrm{d}$...) are significantly different at $\mathrm{P}<0.05$.

Table (1) showed that administration of glucosamine had nonsignificant difference of nutritional values while the osteoarthritis positive control rat group showed a significant decrease in final weight, weight gain, weight gain percent and food intake and non significant difference of FER compared with normal control group. The osteoarthritis rat groups treated with glucosamine sulfate (T.GLAS) and ginger water extract (T.GR) showed a significant decrease of nutritional values compared with normal control but showed significant increase of final weight, weight gain and weight gain percent compared to positive control group. The osteoarthritis rat group which treated with both glucosamine and ginger (T.GLAS+ T. GR) showed a significant improvement of nutritional values and appear a non significant difference compared to normal control values.

After the injection of monosodium iodoacetate to induce osteoarthritis in rats, the lowering in weight gain in first two weeks compared to control group, after that period rats could gained weight in varying proportions in each group (Ali et al., 2016). Oral therapeutic dose of glucosamine helped in restore the body weight decrease caused by induced arthritis in knee joint when compared with the not treated group 
(Hua et al., 2005). The anti-arthritic activity of ginger is the reason of decreasing in body weight gain and food intake, through increasing or decreasing the production of anti-inflammatory cytokines and activating the anti-oxidant defense system (Ramadan et al., 2011and Gumaa et al., 2017).

\section{Biochemical Analysis of blood samples:}

Table (2): CRP, ESR1, ESR2, TP, Albumin, Globulin and A/G Ratio levels of normal and osteoarthritic rat groups

\begin{tabular}{|c|c|c|c|c|c|c|c|}
\hline & $\begin{array}{c}\text { CRP } \\
(\mathrm{mg} / \mathrm{mL})\end{array}$ & $\begin{array}{c}\text { ESR1 } \\
(\mathrm{mm} / \mathrm{hr})\end{array}$ & $\begin{array}{c}\text { ESR2 } \\
(\mathrm{mm} / \mathrm{h})\end{array}$ & $\begin{array}{l}\text { Total } \\
\text { protein } \\
\text { (g/dL) }\end{array}$ & $\begin{array}{l}\text { Albumin } \\
\text { (g/dL) }\end{array}$ & $\begin{array}{c}\text { Globulin } \\
\text { (g/dL) }\end{array}$ & $\begin{array}{c}\text { Albumin / } \\
\text { globulin } \\
\text { ratio }\end{array}$ \\
\hline Normal control & $2.83+0.26 \mathrm{~d}$ & $7.50+0.55 \mathrm{~d}$ & $13.17+1.47 d$ & $7.83+0.34 a$ & $4.63+0.23 a$ & $3.20+0.41 \mathrm{a}$ & $1.48+0.24 b c$ \\
\hline GLAS & $2.60+0.13 \mathrm{~d}$ & $7.17+0.75 \mathrm{~d}$ & $13.00+0.63 d$ & $8.02+0.25 a$ & $4.67+0.48 a$ & $3.35+0.46 \mathrm{a}$ & $1.43+0.32 \mathrm{bc}$ \\
\hline Positive control & $41.00+5.06 a$ & $51.67+1.37 a$ & $84.83+2.23 a$ & $2.98+0.25 \mathrm{c}$ & $2.22+0.32 \mathrm{c}$ & $0.77+0.47 b c$ & $4.44+3.21 \mathrm{a}$ \\
\hline T.GLAS & $19.28+2.19 b$ & $28.17+1.94 b$ & $47.67+2.94 b$ & $5.13+0.30 \mathrm{~b}$ & $3.47+0.38 b$ & $1.67+0.56 \mathrm{~b}$ & $2.33+0.93 a b$ \\
\hline T. GR & $21.77+2.52 b$ & $31.33+2.73 b$ & $50.67+3.01 b$ & $4.85+0.14 b$ & $3.33+0.47 b$ & $1.52+0.48 \mathrm{~b}$ & $2.51+1.26 \mathrm{ab}$ \\
\hline T.GLAS+T.GR & $15.22+1.53 \mathrm{c}$ & 23.33+3.01c & $41.67+3.01 \mathrm{c}$ & $6.97+0.36 \mathrm{ab}$ & $4.12+0.17 \mathrm{ab}$ & $2.85+0.37 \mathrm{a}$ & $1.47+0.22 \mathrm{bc}$ \\
\hline
\end{tabular}

Mean \pm SD values in each column having different combinations of superscript letters $(\mathrm{a}, \mathrm{b}, \mathrm{c}, \mathrm{d} . .$.$) are significantly different at \mathrm{P}<0.05$.

Data in table (2) showed non-significant difference between normal control and GLAS groups in the estimated parameters in this table. The control positive rat group showed a significant increase in serum levels of C- reactive protein (CRP), Erythrocyte sedimentation rate (ESR1 \& ESR2) and albumin / globulin ratio but showed a significant decrease in total protein, albumin and globulin compared with normal and GLAS groups. T.GLAS and T. GR rat groups which administered monosodium iodoacetate with glucosamine sulfate and ginger water extract showed a significant decrease in CRP, ESR1 and ESR2 and significant increase in total protein and albumin compared with positive control group. While T.GLAS $+\mathrm{T}$. GR rat group showed significant decrease in CRP, ESR1 and ESR2 compared with positive control group but non-significant difference of total 
protein, albumin, globulin and Albumin / globulin ratio compared to normal control rat group.

Erythrocyte sedimentation rate (ESR) and C- reactive protein (CRP) are probably the most common laboratory measurement used for detection of inflammation and activity in joint diseases (Keenan et al., 2008). The improvement and decline of CRP and ESR levels were reported by using ginger water extracts in laboratory animals. Ginger was considered safe in the treatment of osteoarthritis and could relieve the pain (Ghavipour et al., 2017 and Mobasheri, 2012). Ginger has anti-inflammatory properties, provided long-term improvement in reduce osteoarthritis pain in knee joint and modifies immune system responses (Mazidi et al., 2016). Glucosamine sulfate drug has therapeutic effect in the treatment of osteoarthritis of the knee, pain relief, increased functional activity and decreased stiffness in the knee joints especially in an early stage of the disease (Shuba et al., 2016). The decline in the values of CRP and ESR of osteoarthritis rats groups is due to synergistic effects of anti-inflammatory activity of ginger extract and anti-inflammatory drug GLAS. Furthermore, total protein is made up of albumin and globulin, used for indication of general health states, or liver and kidney disorders as well as other diseases in different organ systems (Clark and Kruse, 1990). Treatment with different herbs help in increase the total proteins levels, albumin and globulins levels of the blood samples, and this effect lowered A/G ratio levels (El Shemy et al., 2011 and Gumaa et al., 2017). 


\section{Laboratory tests of oxidative stress in knee joint tissue:}

Table (3): CAT, SOD, GPX, GSH antioxidant enzymes and MDA levels in knee joint tissue of normal and osteoarthritic rat groups

\begin{tabular}{||c||c|c|c|c|c||}
\hline & $\begin{array}{c}\text { Catalase } \\
\text { U/mg. protein }\end{array}$ & $\begin{array}{c}\text { SOD } \\
\text { U/mg. protein }\end{array}$ & $\begin{array}{c}\text { GPX } \\
\text { U/mg. protein }\end{array}$ & $\begin{array}{c}\text { GSH } \\
\text { nmol/mg.tissue }\end{array}$ & $\begin{array}{c}\text { MDA } \\
\text { nmol/mg. tissue }\end{array}$ \\
\hline \hline Normal control & $9.80+0.24 \mathrm{a}$ & $922.18+4.33 \mathrm{ab}$ & $320.17+13.80 \mathrm{a}$ & $78.22+1.58 \mathrm{a}$ & $1.53+0.44 \mathrm{c}$ \\
\hline GLAS & $10.27+0.39 \mathrm{a}$ & $937.65+16.04 \mathrm{a}$ & $323.67+22.84 \mathrm{a}$ & $79.38+0.59 \mathrm{a}$ & $1.73+0.47 \mathrm{c}$ \\
\hline Positive control & $1.10+0.51 \mathrm{~d}$ & $331.65+10.41 \mathrm{~d}$ & $116.50+5.47 \mathrm{~d}$ & $31.85+0.89 \mathrm{~d}$ & $15.43+0.50 \mathrm{a}$ \\
\hline T.GLAS & $5.87+0.34 \mathrm{c}$ & $601.52+7.19 \mathrm{c}$ & $226.50+4.97 \mathrm{c}$ & $53.08+1.16 \mathrm{c}$ & $5.55+0.62 \mathrm{~b}$ \\
\hline T. GR & $6.15+0.45 \mathrm{c}$ & $595.25+10.26 \mathrm{c}$ & $221.67+2.94 \mathrm{c}$ & $53.54+1.54 \mathrm{c}$ & $5.87+0.77 \mathrm{~b}$ \\
\hline T.GLAS+ T. GR & $7.78+0.55 \mathrm{~b}$ & $699.00+7.53 \mathrm{~b}$ & $264.00+6.07 \mathrm{~b}$ & $61.50+2.89 \mathrm{~b}$ & $3.73+0.50 \mathrm{bc}$ \\
\hline
\end{tabular}

Mean \pm SD values in each column having different combinations of superscript letters $(\mathrm{a}, \mathrm{b}, \mathrm{c}, \mathrm{d}$...) are significantly different at $\mathrm{P}<0.05$.

As expected, there was a non significant difference in antioxidants enzymes and MDA levels in knee joint tissue between normal control and GLAS groups. Positive control group had very lower values of catalase, GSH, GPX and SOD antioxidant enzymes and high indicative differences of MDA as Oxidative stress in knee joint tissue compare with normal control group. All rats in osteoarthritis groups received treatment dose of glucosamine sulfate (T.GLAS group), ginger water extract (T.GR group) and glucosamine sulfate plus ginger water extract (T.GLAS+T.GR group) had a significant higher values of the tested antioxidants enzymes and lower value of MDA compared to positive group without reach the levels of normal control group ( table 3 ).

Free radicals could be determined by measuring MDA that is a final product of polyunsaturated fatty acids peroxidation in the cells. An increase in free radicals causes overproduction of MDA, marker of oxidative stress, that have been involved in the development of osteoarthritic joint and cancerous patients (Gawel et al., 2004 and Haflah et al., 2009). The water extraction of ginger is a good source of antioxidant as it inhibits the activity of free radicals in different organs particularly in the renal, liver and 
cartilage articular. The antioxidant activities of water extractions of herbs are causing the decrease of MDA and act as anticancer and anti-arthritics factor (Uz et al., 2009, Rahmani et al., 2014and Gumaa et al., 2017). Measurement of antioxidant parameters is useful way for testing the usefulness and effectiveness of treatment agents in preventing the damage in arthritis. Aquatic extracts of medicinal herbs have many benefits in reducing oxidative stress injuries in many diseases by increasing the proportions of antioxidant enzymes such as CAT, GSH, GPX and SOD (Alturfan et al., 2007 and Maizura et al., 2011; Farzaei et al., 2014).

\section{Histopathological analysis of knee joint specimens:}

The specimens isolated from knee joints tissue in normal control group and GLAS group showed a smooth and normal surface of the articular cartilage as perceived in picture $(1 \& 2)$. The specimens isolated from knee joints tissue in positive control group showed decrease in the cartilage thickness in joint space narrowing, with irregular fibrillated and necrosis in cartilage surface, abnormal matrix intensity and chondrocytes, subchondral bone shows irregularity in matrix and shape as perceived in picture (3). The specimens isolated from knee joints tissue in osteoarthritis treatment group with glucosamine sulfate (T.GLAS group) showed small recovery of knee joint, with small necrosis in cartilage surface and increased vascularization in subchondral bone as perceived in picture (4) while the specimens isolated from knee joints tissue in osteoarthritis treatment group with ginger water extract (T.GR group) showed decreases in cartilage thickness, necrosis in cartilage surface and increased vascularization in subchondral bone as perceived in picture (5). The specimens isolated from knee joints tissue in osteoarthritis treatment group with glucosamine sulfate plus ginger water extract (T.GLAS+T.GR group), showed small recovery of knee joint, with small necrosis in cartilage surface and increased vascularization in subchondral bone as perceived in picture (6).

The results of this study are in parallel with chemical results and consistent with the study results of Anderson et al.,2005, Rahmani et al.,2015 and Ali et al., 2016) the study found a partial improvement of the 
articular cartilage of the knee in the pathology pictures when treated with glucosamine and ginger compare whit positive control group.
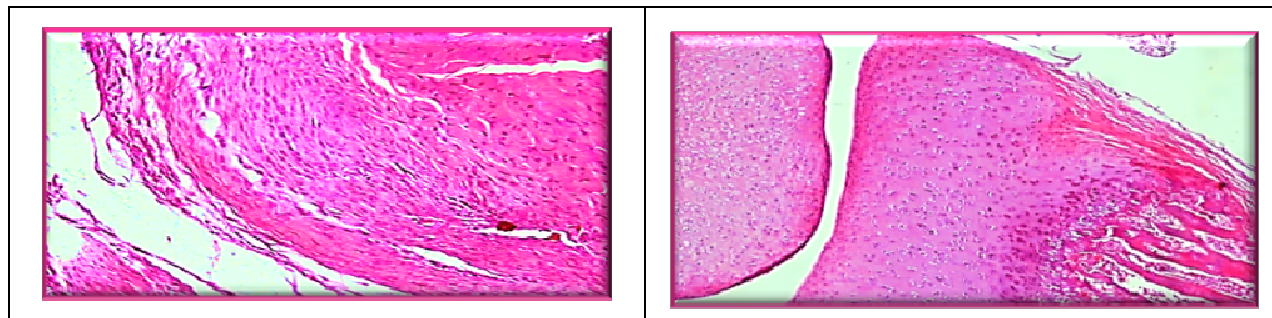

Picture (1): Normal control group showing Picture (2): GLAS group showing a smooth a smooth and normal surface of the articular and normal surface of the articular cartilage cartilage in right knee joints tissue $(\mathrm{H}$ and $\mathrm{E}$ in right knee joints tissue $(\mathrm{H}$ and $\mathrm{E}$ stain, $\times$ stain, $\times 100)$.

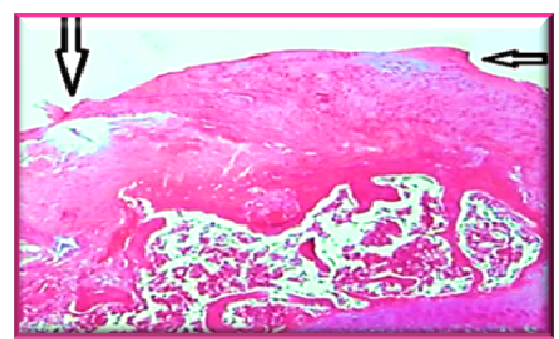
100).

Picture (3): Positive control group showing Picture (4): T.GLAS group showing small decrease in the cartilage thickness in joint in cartilage surface and increased space narrowing, with irregular fibrillated vascularization in subchondral bone $(\mathrm{H}$ and and necrosis in cartilage surface, abnormal E stain, $\times 100$ ).

matrix intensity and chondrocytes, subchondral bone shows irregularity in matrix and shape (H and $\mathrm{E}$ stain, $\times 100)$.
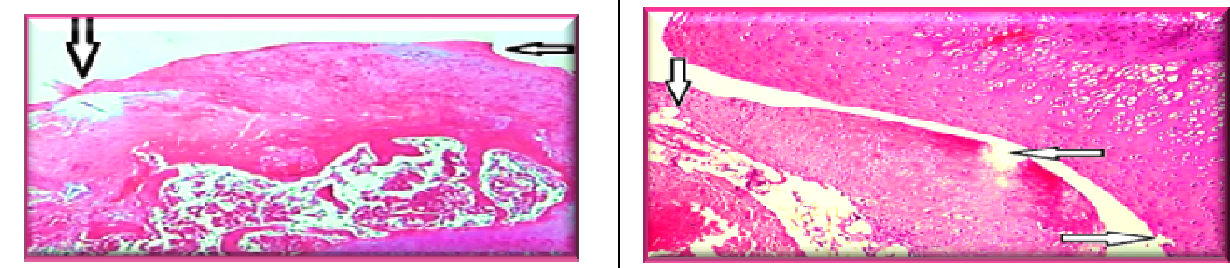

Picture (5): T.GR group with ginger water Picture (6): T. GLAS+T.GR group treated extract which has been injected with MIA, is with glucosamine sulfate plus ginger water showing decreases in cartilage thickness, extract, showing small recovery of knee necrosis in cartilage joint, with small necrosis in cartilage surface and increased vascularization in subchondral bone $(\mathrm{H}$ and $\mathrm{E}$ stain, $\times 100)$. surface and increased vascularization in subchondral bone (H and E stain, $\times 100)$. 
- Therapeutic effects of glucosamine sulfate and ginger extract on monosodium iodoacetate

\section{CONCLUSION}

Administration of glucosamine and ginger extract could alleviate the osteoarthritis in rats and the best results appeared in when treated with both glucosamine and ginger because of synergistic effects. It is recommended to introduce ginger in diet to lower osteoarthritis. Further investigation is needed for examine the mechanism, effective dose and duration of glucosamine and ginger extract in osteoarthritis treatment.

\section{REFERENCES}

- Ahui, M.L.B; Champy, P; Ramadan, A; Van, L.P; Araujo, L; André, K.B; Diem, D; Coulibaly, K.S; Offoumou, A.M; Michel D.Y; Thieblemonta, N and Herbelin, A. (2008): Ginger prevents Th2-mediated immune responses in a mouse model of airway inflammation. Int. Immune. Pharmacol. 8(12): 16261632

- Ali, B.H.; Blunden, G.; Tanira, M.O. and Nemmar, A. (2008): Some phytochemical, pharmacological and toxicological properties of ginger (Zingiber officinale Roscoe): a review of recent research. Food Chem. Toxicol. 46 (2): 409-420.

- Ali, S.M.; Okda, A.A.; dessouky, I.S.; Hewedy, W.A.; Zahran, N.M. and Alamrani, B.A. (2016): L-Carnitine ameliorates knee lesions in monoiodoacetate induced osteoarthritis in rats. Alexandria Journal of Medicine. 53(1): 61-66.

- Anderson, J.W.; Nicolosi, R.J. and Borzelleca, J.F. (2005): Glucosamine effects in humans: a review of effects on glucose metabolism, side effects, safety considerations and efficacy. Food Chem Toxicol. 43: 187-201.

- Alturfan, A.A.; Uslu, E.; Alturfan, E.E.; Hatemi, G; Fresko, I. and Kokoglu, E. (2007): Increased serum sialic acid levels in primary osteoarthritis and inactive rheumatoid arthritis. Tohoku J. Exp Med. 213: 241-248.

- Artimage, G.Y. and Berry, W.G. (1987): Statistical Methods 7th Ed. Ames, Iowa State University Press. 39-63.

- Banchroft, J.; Stevens, A. and Turner, D. (1996): Theory and Practice of Histological Techniques, $5^{\text {th }}$ Ed. Churchill Livingstone. New York. p. 139. 
- Bull, B.S; Caswell, M; Ernst, E; Kallner, A; Koepke, J.A; Lewis, S.M; Lowe, G.D.O; Rampling, M.W. and Stuart, J. (1993): ICSH recommendations for measurement of erythrocyte sedimentation rate. J. Clin. Pathol. 46(3): 198-203.

- Cannon, D.C; Olitzky, I. and Inkpen, J.A. (1974): Proteins In: Clinical chemistry, principles and technics, 2 nd ed. RJ Henery, DC Cannon, JW Winkelman, editors, Harper \& Row, New York, 407-421.

- Chapman, D.G; Castillo, R. and Campbell, J. A. (1959): Evaluation of protein in foods. I.A method for the determination of protein efficiency ratios. Can. J. Biochem. Physiol. 37: 679-686.

- Chetana, V. (1993): Immunology and Infectious Diseases. 3(6): 139-144.

- Choi, H.S.; Im, S.; Park, J.W. and Suh, H.J. (2016): Protective Effect of Deer Bone Oil on Cartilage Destruction in Rats with Monosodium Iodoacetate (MIA)Induced Osteoarthritis. 39(12): 2042-2051.

- Claiborne, A. (1985): Catalase activity. In: CRC Hand-book of methods for oxygen radical research, BocaRaton, ed. by R. A. Greenwald. CRC. Press. 283284.

- Clark, V.L and Kruse, J.A. (1990): Clinical Methods: The History, Physical, and Laboratory Examinations, $3^{\text {rh }}$ Ed. Journal of the American Medical Association 264(21): 2808.

- Coles, E. H. (1974): Veterinary Clinical Pathology. Saunders Company. $2^{\text {th }}$ Ed. Philadelphia and London. Composition, uses and analysis. Food Chem., 38(2): 119-143.

- Dieppe, P.A. and Lohmander, L.S. (2005): Pathogenesis and management of pain in osteoarthritis. Lancet. 365(9463): 965-973.

- Eastham, R. D. (1976): A laboratory guide to clinical diagnosis. $4^{\text {th }}$ Ed. Great Britain. John Wright and Sons Ltd.

- El Shemy, M.A.A.; Abdalla, A.O.B. and Fararh, K.M. (2011): Antioxidant and hepatoprotective effects of ginger in rats. Benha Veterinary Medical J. 22: 714.

- Ellman, G.L. (1959): Tissue sulfhydryl groups. Arch. Biochem. Bio. phys. 82 (1): 70-77.

- Farzaei, M.H.; Farzaei, F.; Gooshe, M.; Abbasabadi, Z.; Rezaei, N. and Abdolghaffari, A.H. (2014): Potentially effective natural drugs in treatment for 
- Therapeutic effects of glucosamine sulfate and ginger extract on monosodium iodoacetate

the most common rheumatic disorder: osteoarthritis. Rheumatology Int. 35: 799814.

- Friedewald, W.T; Levy, R.I. and Frederickson, D.S. (1972): Estimation of concentration of low-density lipoproteins separated by three different methods. Clin. Chem. 28: 2077.

- Gawel, S.; Wardas, M.; Niedworok, E. and Wardas, P. (2004): Malondialdehyde (MDA) as a lipid peroxidation marker. Wiad Lek. 57: 453-5.

- Ghasemzadeh, A.; Jaafar, H.Z. and Rahmat, A. (2010): Antioxidant activities, total phenolics and flavonoids content in two varieties of Malaysia young ginger (Zingiber officinale Roscoe), Molecules 15: 4324-4333.

- Ghavipour, M.; Sotoudeh, G.; Tavakoli, E.; Mowla, K.; Hasanzadeh, J.; Mazloom, Z. (2017): Pomegranate extract alleviates disease activity and some blood biomarkers of inflammation and oxidative stress in Rheumatoid Arthritis patients. Eur. J. Clin. Nutr. 71: 92-96.

- Gross, R.T; Bracci, R; Rudolph, N; Schroeder, E. and Kochen, J.A. (1967): Hydrogen peroxide toxicity and detoxification in the erythrocytes of newborn infants. Blood. 29(4): 481-493.

- Gumaa, S.A.; Hassan, E. M. and Khalifa, D.M. (2017): Hepatoprotective Effect of Aqueous Extracts of Some Medicinal Plant Mixtures on CCl4-Induced Liver Toxicity. IOSR. Journal of Pharmacy and Biological Sciences. 12(1): 4352.

- Guzman, R.E; Evans, M.G; Bove, S; Morenko, B. and Kilgore, K. (2003): Mono-iodoacetateinduced histologic changes in subchondral bone and articular cartilage of rat femorotibial joints: an animal model of osteoarthritis. Toxicol Pathol. 31(6): 619-924.

- Haflah, N.H.; Jaarin, K.; Abdullah, S. and Omar, M. (2009): Palm vitamin E and glucosamine sulphate in the treatment of osteoarthritis of the knee. Saudi Med J. 30: 1432-1438.

- Hua, J.; S, Hirano S; Sakamoto, K. and Nagaoka, I. (2005): Preventive actions of a high dose of glucosamine on adjuvant arthritis in rats. Inflamm. Res. 54: $127-132$ 
- Jerosch, J. (2011): Effects of glucosamine and chondroitin sulfate on cartilage metabolism in OA: outlook on other nutrient partners especially omega-3 fatty acids. Int J, Rheumatology, 969012.

- Keenan, R.T.; Swearingen, C.J. and Yazici, Y. (2008): Erythrocyte sedimentation rate and C-reactive protein levels are poorly correlated with clinical measures of disease activity in rheumatoid arthritis, systemic lupus erythematosus and osteoarthritis patients. Clin. Exp. Rheumatology. 26(9): 814.

- Lane, NE.; Brandt, K.; Hawker, G.; Peeva, E.; Schreyer, E.; Tsuji, W. and Hochberg, M.C. (2011): OARSI-FDA initiative: defining the disease state of osteoarthritis. Osteoarthritic Cartilage, 19(5): 478-482.

- Litwic, A; Edwards, M.H; Dennison, E.M. and Cooper, C. (2013): Epidemiology and burden of osteoarthritis. Br Med Bull.105: 185-199.

- Madsen S; Bartels EM; Stockmarr A; Borgwardt A; Cornett C, Danneskiold-Samsoe B. and Bliddal, H. (2012): A synoviocyte model for osteoarthritis and rheumatoid arthritis: response to ibuprofen, betamethasone, and ginger extract. A cross-sectional in vitro study. Arthritis. 505842. https://doi.org/10.1155/2012/505842.

- Maizura, M.; Aminah, A. and Wan A.W. (2011): Total phenolic content and antioxidant activity of kesum (Polygonum minus), ginger (Zingiber officinale) and turmeric (Curcuma longa) extract. Int Food Res J. 18: 529-534.

- Mazidi, M; Gao, HK; Rezaie, P. and Ferns, G.A. (2016): The effect of ginger supplementation on serum C-reactive protein, lipid profile and glycaemia: a systematic review and meta-analysis. Food. Nutr. Res. 1(60): 32613.

- Mistura, U. and Midora, M. (1987): Determination of Malondialdehyde precursor in tissues by thiobarbituric acid test. Anal. Biochem, 86: 271-8.

- Mobasheri, A. (2012): Intersection of inflammation and herbal medicine in the treatment of osteoarthritis. Curr. Rheumatology .Rep. 14(16): 604.

- Murray, C.J.L. and Lopez, A.D. (2013): measuring the global burden of disease. In World Health Organization. N. Engl J. Med. 369(5): 448-457.

- Nandi, A. and Chatterje, I. B. (1988): Assay of superoxide dismutase activity in animal tissue. J. Biosci. 13(3):305-315. 
- Therapeutic effects of glucosamine sulfate and ginger extract on monosodium iodoacetate

- Necheles, T.E; Boles, T.A. and Allen, D.M. (1968): Erythrocyte glutathione peroxidase deficiency and hemolytic disease of the newborn infant. Journal of Paediatrics, 72: 319.

- Noushi A.A. and Al-Shawi, N.N. (2013): Possible adverse effects of once-daily oral therapeutic dose of either glucosamine sulfate or glucosamine/chondroitin sulfate on blood cells count in rats. Int. Res. J. Pharm. 4 (10): 2230-8407.

- NRC, (1995): National Research Conical, Nutrition Requirements of Laboratory Animals. Forth Revised Edition, Institute for Laboratory Animal Research. National Institute of Health. Academic Press. Washington DC, USA.

- Rahmani, A.H.; Shabrmi, F.M. and Aly, S.M. (2014): Active ingredients of ginger as potential candidates in the prevention and treatment of diseases via modulation of biological activities. Int. J. Physiol. Pathophysiol. Pharmacol. 6: 125-136.

- Ramadan, G.; Al-Kahtani, M.A. and El-Sayed, W.M. (2011): Antiinflammatory and anti-oxidant properties of Curcuma longa (Turmeric) versus Zingiber officinale (Ginger) rhizomes in rat adjuvant-induced arthritis. Inflammation. 34 (4): 291-301.

- Shen, C.L.; Hong, K.J. and Kim, S.W. (2005): Comparative effects of ginger root (Zingiber officinale Rosc.) on the production of inflammatory mediators in normal and osteoarthritic sow chondrocytes. J Med Food 8: 149-153.

- Shimura, Y.; Kurosawa, H.; Sugawara, Y.; Tsuchiya, M.; Sawa, M; Kaneko, H; Furami, I.; Liu, L.; Sadatsuki, R.; Hasa, S.; Iwase, Y.; Kaneko, K. and Ishijima, M. (2013): The factors associated with pain severity in patients with knee osteoarthritis vary according to the radiographic disease severity: a crosssectional study. Osteoarthritic Cartilage. 21(9): 1179-1184.

- Shuba, N; Voronova, T and Khambir T. (2016): The study of the efficacy and safety of glucosamine sulfate in the treatment of patients with knee joint osteoarthritis. J. OTP. 84: 378.

- Simanek, V.; Kren, V.; Ulrichová, J. and Gallo, J. (2005): The efficacy of glucosamine and chondroitin sulfate in the treatment of osteoarthritis: are these saccharides drugs or nutraceuticals. Biomed Pap Med. Fac Univ. Palacky Olomouc Czech Repub. 149(1): 51-56. 


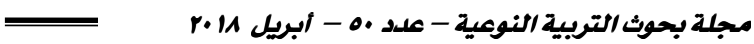

- Tepe, B.; Sokmen, M.; Akpulat, H.A. and Sokmen, A. (2006): Screening of the antioxidant potentials of six Salvia species from Turkey. Food Chem. 95: 200-204.

- Uz, E.; Karatas, O.F; Mete, E.; Bayrak, R.; Bayrak, O.; Atmaca, A.F, Atis, O; Yildirim, M.E. and Akcay, A. (2009): The effect of dietary ginger (Zingiber officinals Rosc) on renal ischemia/reperfusion injury in rat kidneys. Ren Fail. 31: 251-260.

- Velioglu, y. S.; Mazza, G.; Gao, L. and Oomah, B. D. (1998): Antioxidant activity and total phenolics in selected fruits, vegetables, and grain products. J. Agric. Food Chem. 46: 4113-4117.

- Wood, A.M.; Brock, T.M.; Heil, K.; Holmes, R. and Weusten, A. (2013): A Review on the Management of Hip and Knee Osteoarthritis. International Journal of Chronic Diseases. http://dx.doi.org/10.1155/2013/845015. 
- Therapeutic effects of glucosamine sulfate and ginger extract on monosodium iodoacetate

\title{
التأثير العلاجي لكبريتات البلوكوزامين ومستخاص الرنبميل علي خشونة المفاصل بواسطة هونوصوديه ايودوأسيتات في الفئران
}

\author{
إعداد
}

ياسمينا محمد ربيع سلطازن
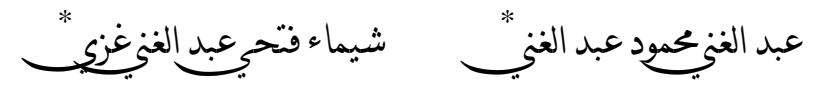

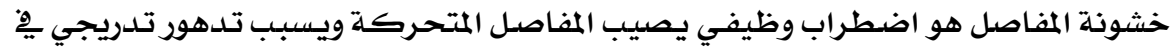

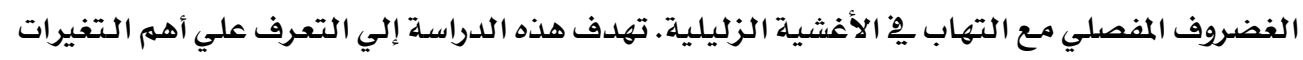

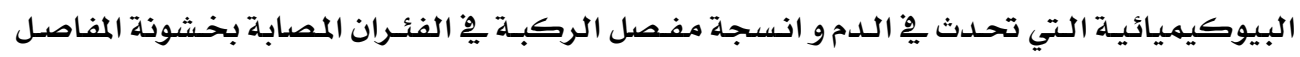

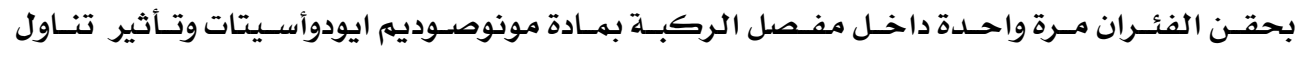

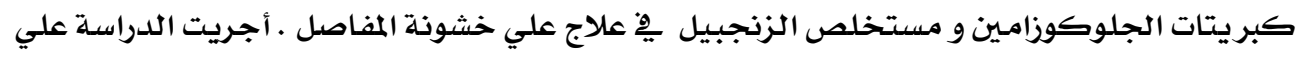

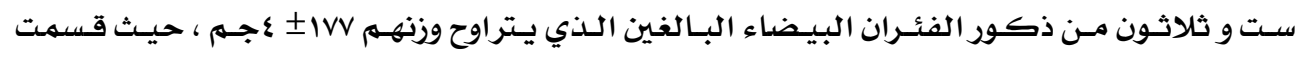

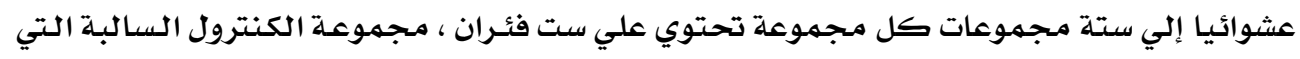

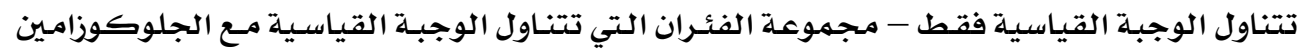

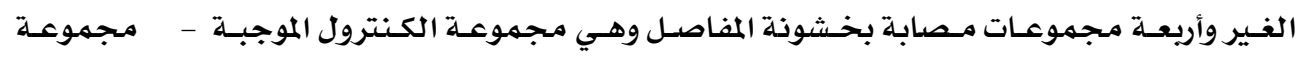

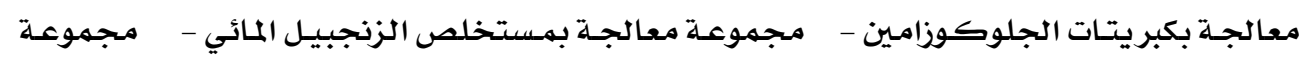

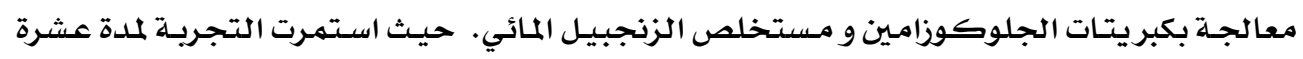

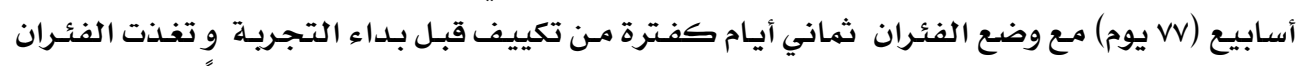

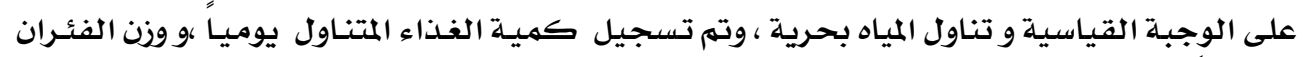

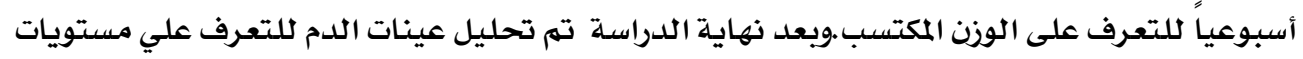

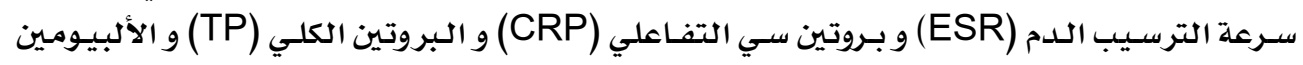

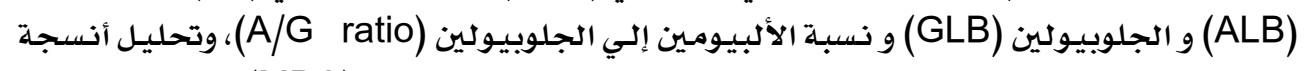

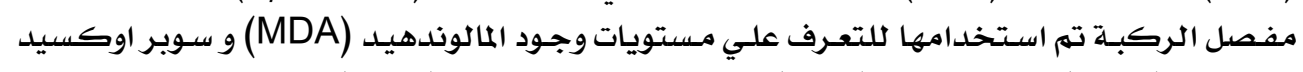

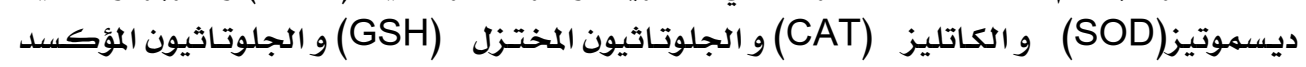

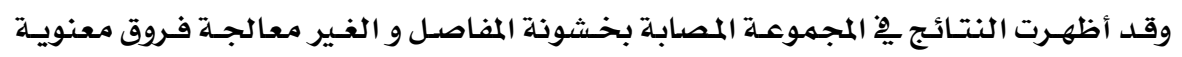

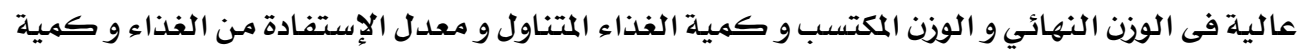

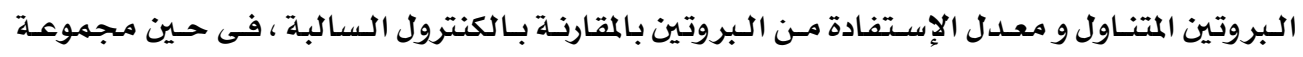

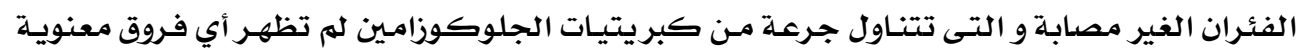




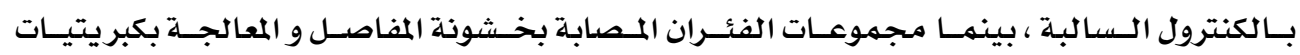

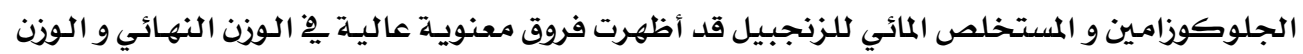

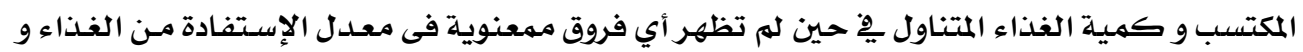

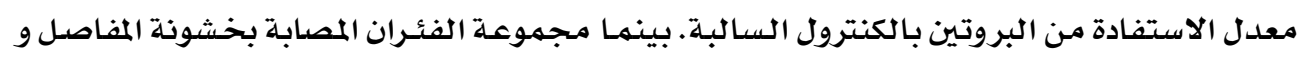

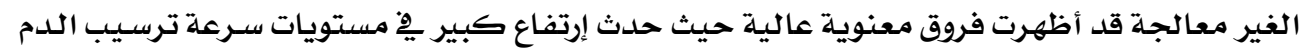

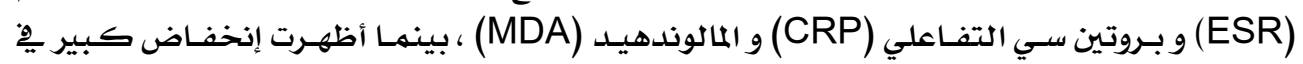

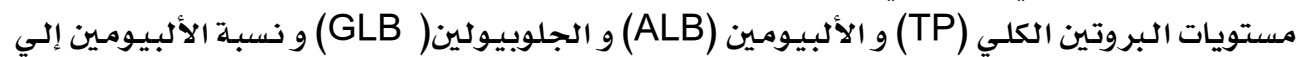

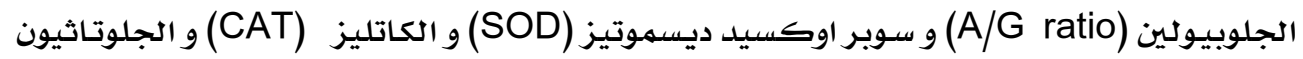

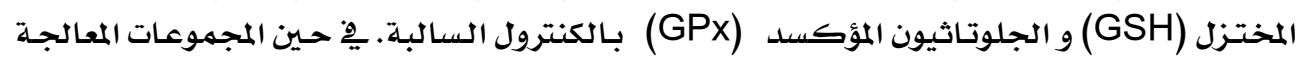

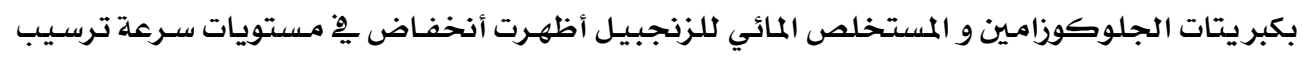

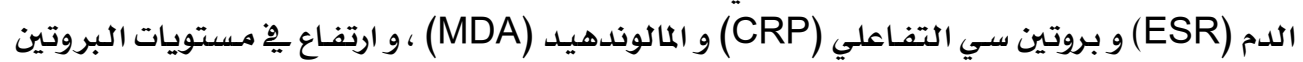

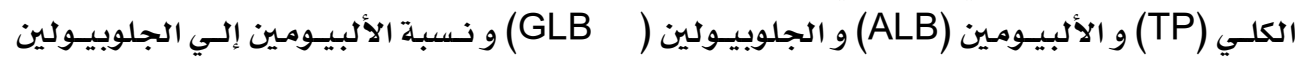

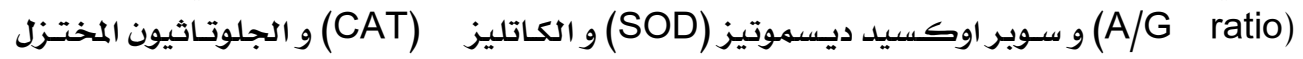

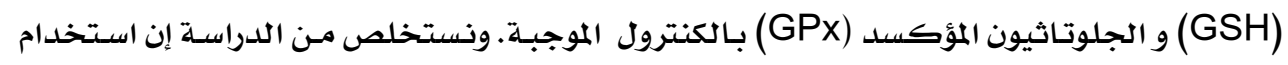

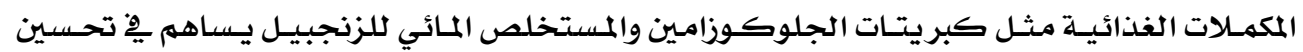

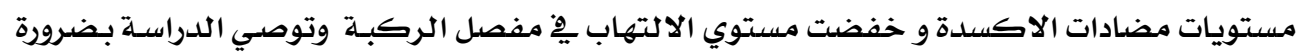

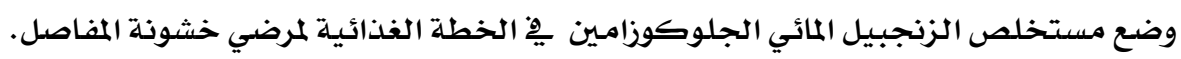
الكلمات المفتاحية: خشونة المفاصل - مونوصوديم أيودوأستيات - كبريتات الجلوكوزامـين

- زنجبيل. 